\title{
The Impact of Paradigm Development and Course Level on Performance in Technology-Mediated Learning Environments
}

\author{
Steven Hornik, Carol Stoak Saunders, Yuzhu Li, Patsy D. Moskal, \\ and Charles D. Dzuiban \\ University of Central Florida, Orlando, Florida, USA
}

shornik@bus.ucf.edu; csaunders@bus.ucf.edu; yli@bus.ucf.edu; pdmoskal@pegasus.cc.ucf.edu; Dziuban@mail.ucf.edu

\begin{abstract}
We investigate the effect of paradigm development and course level on the outcomes of web based technology-mediated learning environments in order to ascertain if these external factors can help explain student outcomes. Using an institutional database of student outcomes, we were able to examine data from over 13,000 students in 167 undergraduate courses from the years 1997 -2003 . Using this data we examined the question which types of courses are best suited for delivery using web-based technologies. The findings indicate that technology-mediated learning can be used more effectively for some courses than others. Our results suggest that student grades are significantly higher and withdrawal rates lower for courses with high paradigm development (e.g., Biology, Computer Science) than for courses with low paradigm development (e.g., Sociology, English). Even stronger relationships emerge when including the hypothesized moderating effect of course level (introductory or advanced). When taking course level into account, student satisfaction is better in advanced high paradigm classes than in advanced low paradigm classes. The opposite holds when comparing satisfaction in introductory low paradigm classes with introductory high paradigm classes. Withdrawal rates are lower in advanced high paradigm classes than introductory high paradigm classes, while the opposite holds for low paradigm classes, with introductory low paradigm classes having lower withdrawal rates than advanced low paradigm classes.
\end{abstract}

Keywords: Technology-mediated learning environments, paradigm development

\section{Introduction}

Universities and business organizations are increasingly turning to technology-mediated learning as an educational tool (Dumort, 2000). Worldwide spending on online education exceeded $\$ 9$

billion in 2003 and was in the $\$ 12-\$ 14$

Material published as part of this publication, either on-line or in print, is copyrighted by the Informing Science Institute. Permission to make digital or paper copy of part or all of these works for personal or classroom use is granted without fee provided that the copies are not made or distributed for profit or commercial advantage AND that copies 1) bear this notice in full and 2) give the full citation on the first page. It is permissible to abstract these works so long as credit is given. To copy in all other cases or to republish or to post on a server or to redistribute to lists requires specific permission and payment of a fee. Contact Publisher@InformingScience.org to request redistribution permission.

billion range in 2004 , with a $30 \%$ annual e-learning spending increase through 2008 (Sarker \& Nicholson, 2005). Estimates indicate that 2,000,000 students take online postsecondary courses (Galt Gobal Review, 2001) and predictions are that the number of university and colleges offering web-based courses will continue to increase. The Condition of Education Report 2002 by the National 
Center for Education Statistics reported that undergraduate and graduate students participated in distance education at the rate of $8 \%$ and $12 \%$, respectively (Wirt \& Livingston, 2002). By far the most common method of participation was via the Internet $-60 \%$ for undergraduates and $68 \%$ for graduates.

As we increasingly rely on this new tool, it is becoming painfully obvious that there is much that we still need to learn about its effective use. Recent studies investigated various ways to use this tool to improve student performance by assessing participation in student study groups, the number of web pages accessed by students (Wang \& Newlin, 2002), the level of effort on homework (Dutton, Dutton, \& Perry, 2001), and by examining learning styles and patterns of usage (Lu, Yu, \& Liu, 2003). Researchers have assessed student performance by grades (Christophel, 1990), satisfaction (Biner, 1993; Gunawardena, 1995), and withdrawal rate (Phipps \& Merisotis, 1999). A review of the learning effectiveness of Asynchronous Learning Networks (ALN) by Swan (2003) indicated that interaction with course content (Swan et al., 2000), interaction with instructors (Arbaugh, 2001; Picciano, 1998), interactions with classmates (Richardson \& Swan, 2003), and vicarious interactions (Sutton, 2001), all improved learning. But, these studies implicitly assume Information Technology (IT) may be effectively applied in all learning environments.

\section{Course Suitability in Technology-Mediated Learning (TML) Environments}

Although past research has compared face-to-face teaching with technology-mediated learning environments, we concentrate instead on comparing the use of IT in learning environments without any face-to-face communications. Technology-mediated learning environments (TML environments) are environments "in which the learner's interactions with learning materials (readings, assignments, exercises, etc.), peers, and /or instructors are mediated through advanced information technology" (Alavi \& Leidner, 2001, p.2) such as the web. For as long as there have been "distant" modes of learning, research has been conducted to examine if it is as good as "traditional" methods of delivery. While some studies find differences in effectiveness when comparing IT-mediated and traditional face-to-face learning environments, many studies indicate that there are no significant differences (Russell, 1999; Sarker \& Nicholson, 2005). We believe that it is time to investigate more systematically what makes technology-mediated learning environments different (more effective in some circumstances, while less effective in others), rather than simply trying to emulate the face-to-face experience in an online environment. That is, "by focusing on whether we can do the old things just as well in different ways, we are blind to the possibilities of doing new and different things" (McDonald, 2002 p.11). The University (virtual or otherwise) is still an organization which needs to avoid the pitfall of expecting technology to increase effectiveness just by being used; rather we need to turn our attention to how it is used.

TML effectiveness studies (vis a vis face-to-face) have been conducted predominantly via field experimentation, surveys, or quasi-experiments (non-random comparison of face-to-face with online courses). A course is defined here as an organized series of lessons about a specific subject. While these studies offer preliminary findings about what courses might best be suited for delivery over the web, a more comprehensive sample is necessary to understand TML applications from the broader institutional perspective. Having data regarding course outcomes from a large number of courses across varied disciplines (or field of study) seems more appropriate. In this study we use an archival research approach that is primarily concerned with the ex post facto examination of historical documents. It allows a systematic investigation of courses to determine if course characteristics might explain TML outcomes. 


\section{Teaching Effectiveness in TML Environments}

"For what type of courses, if any, is this new teaching medium effective?" is a question seldom asked. As suggested by Piccoli, Ahmad and Ives (2001, p. 408), "Considerable uncertainty remains regarding the subject matter and content type best suited to delivery in the virtual environment". In their exploratory analysis of the "myth' that any course can be taught online, Sarker and Nicholson (2005) found that both instructors and students indicated that certain kinds of courses were more (or less) suitable for online delivery. For example, some students stated: "I personally find it difficult to learn math, programming, and high-logic based courses this way. What I find easiest is writing or critical thinking style classes," or "Certainly courses involving easier concepts and less instruction, such as English or humanities courses, are easier on an online environment that programming or database courses" (Sarker \& Nicholson, 2005, p. 66).

Benbunan-Fich and Hiltz (2002) examined the effect of teaching medium (ALN) on course type, in which they categorized courses as those that were more technical and having a heavy emphasis on mathematical analysis and those that were less technical and having a qualitative posture. They found that the less technical courses resulted in higher student grades and better perceptions of learning. Similarly, Vaverek and Saunders (1993-1994) found that students considered courses like Organization Theory to be more appropriate for computer conferencing than were more technical courses such as Statistics/Epidemiology and Accounting/Finance-findings opposite from what the researchers hypothesized. We think that extent of paradigm development and level of course offers an explanation for these differences between the hypotheses and the actual findings about the effectiveness of IT use for teaching.

The paper next discusses paradigm development, its use in prior research and the possible effect that course level might play in explaining those earlier results. We next introduce our research model along with our hypotheses, followed by a discussion of the methodology used to analyze our large dataset and the results. The paper concludes with a discussion of those results and limitations of our present research effort.

\section{Paradigm Development and Course Level}

A theoretical paradigm represents a "constellation of beliefs, values, techniques, shared by members of a given community" (Kuhn, 1970, p. 175). In disciplines with more highly developed paradigms, there is general agreement on common definitions and accepted methodology, and often key concepts are represented through formulas. The physical sciences (i.e., Physics and Chemistry) are believed to have more highly developed paradigms than the social sciences (i.e., Psychology and Sociology) (Beyer, 1978; Kuhn, 1970; Lodahl \& Gordon, 1972; Salancik, Staw, $\&$ Pondy, 1980). In contrast, the MIS discipline is full of debate about what even constitutes its core. Benbasat and Zmud (2003) attempted to define the core. However, numerous articles, as evidenced by the 2003 special issue of Communications of AIS with responses to this article, and the comments of Agarwal and Lucas (2005) suggest that the definition of the core is not agreed upon by members of the discipline. Furthermore, considerable debate, as found in the article by Robey (2003; Also see Hassan, 2006) argue against having a single paradigm in the MIS discipline.

We argue that paradigm development impacts the effectiveness of learning environments. Learning environments fall along a continuum of technology mediation. One end of the continuum is anchored by an environment in which all delivery is face-to-face and there is no technological support whatsoever. The other end of the continuum is an environment in which the delivery is entirely based on the use of advanced information technologies. These two types of learning environments are distinguished by their degree of social presence and media richness. Learning environments that are entirely technology-mediated, especially for relatively short-term college 
classes, could be expected to be less rich (Daft \& Lengel, 1986) than face-to-face learning environments. In particular, in learning environments that are entirely technology-mediated faculty must learn to adapt to the challenges and advantages offered by the technology. They often find that the feedback is slower, the ability to transmit across multiple channels is reduced, and the ability to personalize the communication is less when compared to face-to-face learning environments at the other end of the continuum, at least over the short-term when courses are delivered. Thus, media richness differences are expected to impact the delivery of course materials in different learning environments.

Paradigm development has consequences for the communication of course material. The greater the paradigm development, the more structured is the discipline and the easier it is to communicate its critical terms and concepts. In disciplines with higher paradigm development, there is more agreement about course content. Because students in these disciplines face less ambiguity than in disciplines with low paradigm development, we argue that the greater the paradigm development, the easier it is to communicate course content in TML environments. Thus, TML environments may be a good match for the information processing requirements found in disciplines with high paradigm development (Cheng, 1984). In TML environments, therefore, student performance, as measured by their grades, may be higher in disciplines with high paradigm development than in courses in disciplines with low paradigm development. In high paradigm development courses in TML environments, students should also be more satisfied with their course and more certain about their mastery of course content. Consequently, a smaller percentage of students drop out of the course when compared to students in courses in disciplines with low paradigm development.

While there is theoretical support for paradigm development impacting TML environment effectiveness, the research results are contradictory. In their study of a masters-level professional health care program in the mid 1980s that pioneered heavy reliance on computer conferencing, Vaverek and Saunders (1993-1994) found that in courses in disciplines with higher paradigm development (i.e., Statistics Epidemiology and Accounting/Finance), students evaluated the courses as less appropriate for computer conferencing than courses in disciplines with lower paradigm development (i.e., Organization Theory and Comparative Health Care Systems). Vaverek and Saunders conjectured that the technology-mediated learning environment offered a relatively lean medium of communication (Daft \& Lengel, 1986), which made it difficult to exchange complex key course concepts to which they were being introduced (Vaverek \& Saunders, 1993-1994). Even though there was a high level of agreement about core concepts in disciplines with highly developed paradigms, the students were unfamiliar with the complex concepts. Webster and Hackley (1997) supported this conjecture when they discovered that students reported higher learning outcomes if they perceived the technology used in the learning environment to be rich. Further, feedback in the TML environment was more delayed than in a face-to-face learning environment. That is, the need to understand key terms and concepts may have been more pronounced in courses in disciplines with high paradigm development. Failure to grasp this understanding in a timely manner may have frustrated students, hurt their performance, and lowered their satisfaction with the course. Hence, it is arguable that in courses in disciplines with a high paradigm development, student satisfaction with the course and student grades are lower than in courses with low paradigm development. Further, courses in disciplines with high paradigm development might have higher withdrawal rates than courses in disciplines with low paradigm development. 


\section{Bloom's Taxonomy and TML Environments}

Paradigm development of a discipline is an important characteristic that can help explain outcomes in TML; another important characteristic of a course within a discipline is the level of the course. That is, each course can be placed on a continuum from introductory to advanced.

The extent to which a course is introductory or advanced may be understood using Bloom's taxonomy. Bloom's taxonomy (Bloom, Engelhart, Furst, Hill, \& Krathwohl, 1956) emphasizes building higher level skills from the foundation of lower level skills. Synthesizing interrelated information transpires after mastery of concepts and principles, which occurs after the mastery of remembering facts. Based on the revised taxonomy (Anderson \& Krathwohl, 2001) knowledge is built up from factual knowledge - basic elements students must learn to be acquainted with a discipline - to procedural knowledge - how to do something within a discipline. Cognitively, movement towards higher levels of knowledge proceeds along the dimensions of remembering facts, and understanding, applying, analyzing, evaluating and finally creating knowledge.

\section{Course Level as a Moderator}

TML environments are adaptable to different learning objectives based on Bloom's taxonomy (Chyung \& Stepich, 2003). The increased structure and consensus regarding factual knowledge in high paradigm disciplines allows for easier dissemination and comprehension of critical terms, concepts, and methodologies, especially in more advanced courses. For example, with an understanding of circuits, advanced computer science courses can explore the different methods, materials, etc. used to create circuits, and TML can be leveraged for building simulations or by using CAD. In the advanced political science class, field studies of various forms of democracy might be required, which is more difficult to enable via TML. The notion of course level moderating the effects of paradigm development is consistent with the findings of Vaverek and Saunders (1993-1994) since most of the courses in their study were introductory courses. Hence, it is proposed that course level acts as a moderating variable in the relationship between student outcomes and paradigm development.

\section{Research Model and Hypotheses}

These relationships between student learning outcomes and learning environment and paradigm development, moderated by level of course, are represented in Figure 1 and serve as the basis for the general hypothesis and four specific hypotheses.

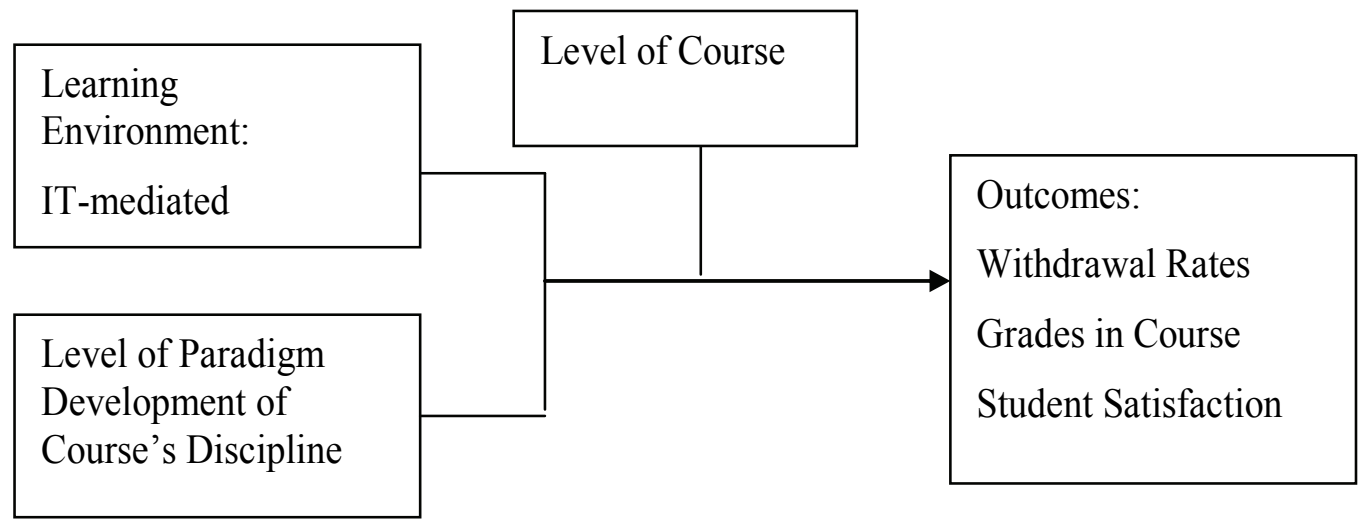

Figure 1. Research Model 
Based on the above discussion we believe that paradigm development, moderated by course level, can help to explain the outcomes reported in prior TML research, and thus we hypothesize the following:

General Hypothesis. Level of course moderates the relationship between paradigm development and student performance in TML environments. In particular,

Hypothesis 1: In introductory courses in disciplines with low paradigm development, student outcomes (i.e., grades and satisfaction) are higher than in introductory courses with high paradigm development in TML environments.

Hypothesis 2: In introductory courses in disciplines with low paradigm development, withdrawal rate is lower than in introductory courses with high paradigm development in TML environments.

Hypothesis 3: In advanced courses in disciplines with low paradigm development, student outcomes (i.e., grades and satisfaction) are lower than in advanced courses with high paradigm development in TML environments.

Hypothesis 4: in advanced courses in disciplines with low paradigm development, withdrawal rate is higher than in advanced courses with high paradigm development in TML environments.

To demonstrate the impact of level of course on the relationship between student outcomes, in Figure 2 we contrast outcomes in introductory courses with outcomes in advanced courses that use WebCT.

\begin{tabular}{|c|c|c|}
\hline & $\begin{array}{l}\text { LOW PARADIGM } \\
\text { DEVELOPMENT }\end{array}$ & $\begin{array}{l}\text { HIGH PARADIGM } \\
\text { DEVELOPMENT }\end{array}$ \\
\hline $\begin{array}{l}\text { INTRODUCTORY } \\
\text { COURSE }\end{array}$ & $\begin{array}{l}\text { Higher Grades } \\
\text { Higher Satisfaction } \\
\text { Lower Withdrawal }\end{array}$ & $\begin{array}{l}\text { Lower Grades } \\
\text { Lower Satisfaction } \\
\text { Higher Withdrawal }\end{array}$ \\
\hline ADVANCED COURSE & $\begin{array}{l}\text { Lower Grades } \\
\text { Lower Satisfaction } \\
\text { Higher Withdrawal }\end{array}$ & $\begin{array}{l}\text { Higher Grades } \\
\text { Higher Satisfaction } \\
\text { Lower Withdrawal }\end{array}$ \\
\hline
\end{tabular}

Figure 2. Level of Course as Moderator in Technology-Mediated Learning Environment

\section{Methodology}

\section{Procedures}

To test the hypotheses, we used data gathered at a large, rapidly-growing metropolitan university in the Southeast of the USA. The university's student base consists of traditional students, approximately two-thirds of whom attend the university on a full-time basis. In the Spring 2004 semester at this University, a record number of 8,750 students enrolled in fully web-based courses, a 22 percent increase from the Fall 2003 semester. This enrollment in fully web-based courses represented almost six percent of the University's total enrollment for the semester. The data for this study were stored in an institutional database that tracked the performance of students in entirely web-based classes and in an institutional database with the student class evaluations. The institutional web-based classes database included data about the class (course number, section, year and semester offered), as well as information about each student enrolled in the class (i.e., grade in class, whether or not the student completed the class, age, grade point average [GPA] and SAT scores). The student class evaluation database had student responses for each class sec- 
tion; there were no student identifiers in this database. The research database was generated using the section number, course number, year and semester to link the student class evaluation database and the web-based classes' database. The data for this study gathered the responses of 13,167 students in 167 undergraduate classes from the spring semester 1997 through the spring semester 2003. We included only web-based courses in disciplines that could be clearly classified as having low or high level of paradigm development in the study and selected only undergraduate courses to avoid difficulty in correctly classifying level of course for graduate courses. Graduate courses are a priori advanced, yet some clearly provide introductory material.

\section{Dependent Variables}

The dependent variables - student satisfaction with the learning environment, grade earned, and student withdrawal rate - are averaged for each class. The independent variable is paradigm development and the moderating variable is course level. The research design controls for learning environment by including only courses whose mode of delivery was entirely IT-mediated (i.e., web-based). Statistical control is applied to a number of other control variables: average age, total SAT scores, University GPA, perceived teacher quality in each class, class size, and the year the class was taught. Measurement for all outcome variables, and for all control variables except class size and the year the class was taught, is at the individual level and aggregated to the class level. (Note: there may be one or more classes taught for each course.) Paradigm development, course level, class size, and year of the class are determined for each class. The unit of analysis is the class.

Student Satisfaction with the Learning Environment- average student rating (on 5-point Likert scale) on two questions included on the class evaluation surveys administered at the end of each semester for each section throughout the university. These two questions measure student satisfaction with learning environment ("Communication of ideas and information" and "Facilitation of learning"). These two items from the class survey were found to be the most important items that identified teaching excellence and effectiveness (Dzubian, Wang, \& Cook, 2003), and thus were selected to capture information about student satisfaction with the learning environment. The items are scored from Excellent (1) to Poor (5). The Cronbach alpha for student satisfaction is .93, which means that the questionnaire items of student satisfaction have high reliability (well above the 0.70 acceptable level suggested by Nunally \& Bernstein, 1994).

Student Grade- average grade earned by students in the section of the class in which $4.0=A$, $3.0=\mathrm{B}, 2.0=\mathrm{C}, 1.0=\mathrm{D}, 0.0=\mathrm{F}$.

Withdrawal Rate- (Number of students who officially dropped the section of the class/ Number of students officially enrolled in the section on the twelfth class day) $* 100$.

Paradigm Development - Categorization based on the research findings by Lodahl and Gordon (1972), Salancik, Staw and Pondy (1980), Pfeffer and Moore (1980), and Cheng (1984) were used to classify Physics and Chemistry, Biology, Mathematics, and Electrical Engineering as high paradigm development disciplines. Consistently ranked as low paradigm development disciplines were Sociology and Political Science (Lodahl \& Gordon, 1972; Pfeffer \& Moore, 1980; Salancik et al., 1980) and Anthropology and History (Pfeffer \& Moore, 1980; Salancik et al., 1980); Pfeffer and Moore (1980) also placed English and Philosophy within the low paradigm development range. Table 1 indicates the disciplines used in this study, the number of sections of web-based undergraduate courses offered in each discipline, the number of students enrolled in courses in each discipline, the number of courses in the prerequisite chain for an undergraduate major and, if available, past classifications of the discipline supporting the coding as high or low paradigm development. 
Since researchers in the past did not include some disciplines in studies of paradigm development (i.e., Management Information Systems, Computer Science, Nursing, Health Services, Social Work, Criminal Justice, Legal Studies, Psychology, and Vocational Education), the paradigm development for all disciplines in the study was validated. To validate paradigm development, consistent with past studies, the number of courses in the undergraduate prerequisite chain in each of the uncategorized disciplines at the University was determined: the shorter the chain, the lower the paradigm development (Pfeffer \& Moore, 1980; Salancik et al., 1980). The Mann-Whitney test found a difference significant at the .001 level between chain length for low (mean $=3.11$ ) vs. high paradigm development $($ mean $=7.25)$ disciplines, supporting the premise that chain length can be used to categorize disciplines by paradigm development.

Table 1: Disciplines Included in Study

\begin{tabular}{|c|c|c|c|c|}
\hline Discipline & $\begin{array}{l}\text { \# Courses (\# } \\
\text { Sections of } \\
\text { course) }\end{array}$ & \# Students & $\begin{array}{l}\text { \# Courses in } \\
\text { Prerequisite } \\
\text { Chain }\end{array}$ & Past Classifications \\
\hline \multicolumn{5}{|c|}{ HIGH PARADIGM DEVELOPMENT (HPD) (coded as ' 1 ') } \\
\hline Biology & $1(1)$ & 25 & 9 & $\begin{array}{l}\text { Lodahl \& Gordon (1972); Pfeffer } \\
\text { \& Moore (1980) }\end{array}$ \\
\hline Computer Science & $1(19)$ & 3,258 & 6 & \\
\hline Nursing & $3(6)$ & 188 & 7 & \\
\hline Health Services & $9(53)$ & 3,018 & 7 & \\
\hline Totals - HPD & $14(79)$ & 6,489 & Mean $=7.25$ & \\
\hline \multicolumn{5}{|c|}{ LOW PARADIGM DEVELOPMENT (LPD) (coded as ‘0’) } \\
\hline Criminal Justice & $4(31)$ & 2,202 & 3 & \\
\hline English & $4(10)$ & 257 & 3 & Pfeffer \& Moore (1980) \\
\hline Political Science & $5(8)$ & 236 & 2 & $\begin{array}{l}\text { Lodahl \& Gordon (1972); Salan- } \\
\text { cik, Staw \& Pondy (1980); Pfef- } \\
\text { fer \& Moore (1980) }\end{array}$ \\
\hline Legal Studies & $1(8)$ & 362 & 4 & \\
\hline $\begin{array}{l}\text { Management } \\
\text { Information } \\
\text { Systems }\end{array}$ & $1(5)$ & 1,814 & 3 & \\
\hline Psychology & $1(4)$ & 147 & 3 & \\
\hline $\begin{array}{l}\text { Sociology \& } \\
\text { Anthropology }\end{array}$ & $5(16)$ & 1,310 & 3.5 & $\begin{array}{l}\text { Lodahl \& Gordon (1972); Salan- } \\
\text { cik, Staw \& Pondy (1980); Pfef- } \\
\text { fer \& Moore (1980) }\end{array}$ \\
\hline $\begin{array}{l}\text { Vocational } \\
\text { Education }\end{array}$ & $1(6)$ & 350 & 3 & \\
\hline Totals - LPD & $22(88)$ & 6,678 & Mean $=3.111$ & \\
\hline $\begin{array}{l}\text { OVERALL } \\
\text { TOTALS }\end{array}$ & $36(167)$ & 13,167 & & \\
\hline
\end{tabular}

Course Level - Introductory courses are the first or survey course in each of these disciplines, coded as ' 0 '. Advanced courses have at least two prerequisites and/or are described as advanced in the course catalog. Advanced courses were coded as ' 1 '. To determine the course level (i.e., 
introductory or advanced), the catalog descriptions for all course included in the analysis were examined and prerequisites were determined. Then two researchers separately coded the courses. The course classification was then verified by the course instructor via e-mail. As a result of instructor feedback 5 courses were reclassified. Cohen's original kappa (Cohen, 1960) for the coding was .66 after the verification, which indicates substantial agreement since the kappa coefficient falls into the range of 0.6 to 0.79 (Landis \& Koch, 1977).

\section{Control Variables}

Control of learning environment was provided through a research design that only included courses that used WebCT as the TML environment. Because the data gathered was from an institutional database, it was possible to incorporate more control than is typically possible in lab experiments or field studies. Class size was used to statistically control for any effects due to large class enrollments (Arbaugh \& Duray, 2002; Hiltz \& Wellman, 1997); SAT score and prior university GPA were used to control for ability because research indicated that they relate to performance (Higgs \& Wood, 1999; VandeWalle. Cron, \& Slocum, 2001). Perceived teacher quality was used to minimize effects associated with the instructor in the WebCT environment, including the instructor's facility with WebCT. Likewise the year in which the course was taught was used to minimize differences from the use of various versions of WebCT during the time period of this study. In addition, age was used to control for student maturity and experience. The controls are operationalized as follows:

Learning Environment - technology-mediated classes in which the students are dispersed and the delivery is entirely over the web using WebCT. The WebCT classes were prepared by a support staff person who worked with the class instructor during and after the instructor had completed a semester-long training session on using WebCT effectively for online learning. Standard templates were used to develop the classes. The communication support provided by WebCT is high and includes chat rooms, a whiteboard, e-mail capabilities, and discussions via WebCT's bulletin board feature. Thus, students can provide input anonymously and communicate synchronously and asynchronously with other students and faculty. The system maintains complete records of online discussions. Although WebCT has a calendar feature, its process support could be considered low to medium because it does not promote agenda setting or enforcement. Little support is provided for information processing through WebCT. Students can submit assignments, take quizzes or check their grades and course content. However, system features are not available to help them in evaluating or aggregating course content information.

Age-average age of students in the class section at the semester beginning.

Total SAT-average total SAT composite score for students enrolled in the class section.

GPA-average University GPA of students enrolled in the class section at the beginning of the semester in which the class was taken.

Perceived Teacher Quality-average student rating (on 5-point Likert scale) on an overall class evaluation question included on the class evaluation surveys administered at the end of each semester in each section throughout the university. The question "Overall assessment of instructor?" was scored from Excellent (1) to Poor (5). Overall student satisfaction served as a proxy for the quality of the teacher.

Class size-number of students enrolled in class on the twelfth class day.

Year-academic year in which the class was taught. The data base included classes taught from Fall 1997 through Spring 2003. Year served as a proxy variable for technical changes in content delivery that occurred over the six years that the study covered. 
The results of our analysis to assess direct and interaction effects, based on MANCOVA and univariate analyses, are discussed next. The results of the hierarchical moderated regression analysis to test for interaction effects follow.

\section{Results}

Descriptive statistics for student grade, student satisfaction, and withdrawal rate by course level (i.e., introductory or advanced) and by paradigm development (i.e., high or low) are provided in Table 2.

Table 2: Descriptive Statistics

\begin{tabular}{|c|c|c|c|c|c|}
\hline & Paradigm & Course Level & Mean & $\begin{array}{l}\text { Standard Devia- } \\
\text { tion (std dev) }\end{array}$ & $\mathrm{N}$ \\
\hline \multirow[t]{6}{*}{ Student Grade } & $\begin{array}{l}\text { Low Para- } \\
\text { digm }\end{array}$ & Introductory & 2.9180 & .47444 & 69 \\
\hline & & Advanced & 3.0762 & .39655 & 10 \\
\hline & & Total & 2.9380 & .46603 & 79 \\
\hline & $\begin{array}{l}\text { High Para- } \\
\text { digm }\end{array}$ & Introductory & 3.2987 & .33906 & 18 \\
\hline & & Advanced & 3.5170 & .22432 & 33 \\
\hline & & Total & 3.4400 & .28705 & 51 \\
\hline \multirow[t]{6}{*}{$\begin{array}{l}\text { Withdrawal } \\
\text { Rate }\end{array}$} & $\begin{array}{l}\text { Low Para- } \\
\text { digm }\end{array}$ & Introductory & .1178 & .09432 & 69 \\
\hline & & Advanced & .2430 & .11424 & 10 \\
\hline & & Total & .1336 & .10496 & 79 \\
\hline & $\begin{array}{l}\text { High Para- } \\
\text { digm }\end{array}$ & Introductory & .0819 & .05722 & 18 \\
\hline & & Advanced & .0375 & .03614 & 33 \\
\hline & & Total & .0531 & .04909 & 51 \\
\hline \multirow[t]{6}{*}{$\begin{array}{l}\text { Student Satis- } \\
\text { faction }\end{array}$} & $\begin{array}{l}\text { Low Para- } \\
\text { digm }\end{array}$ & Introductory & 1.9649 & .42771 & 69 \\
\hline & & Advanced & 2.4834 & .31074 & 10 \\
\hline & & Total & 2.0306 & .44802 & 79 \\
\hline & $\begin{array}{l}\text { High Para- } \\
\text { digm }\end{array}$ & Introductory & 2.4377 & .60923 & 18 \\
\hline & & Advanced & 1.8187 & .33070 & 33 \\
\hline & & Total & 2.0372 & .53425 & 51 \\
\hline
\end{tabular}




\section{MANCOVA Results}

The relationship between paradigm development and each outcome was tested by running MANCOVA for the dependent variables (student satisfaction, student grade, withdrawal rate) with the independent variables (paradigm development, course level), and with the covariates (age, total SAT, university GPA, perceived teacher quality, class size, and year). Univariate normality of each dependent variable was assessed using Shapiro-Wilk's test. While the results of ShapiroWilk's test are significant for student grade, withdrawal rate, and student satisfaction, further examination of skewness, kurtosis, and the normal probability plots suggests that the assumption of normality is met. The Levene test of equality of error variances is insignificant for withdrawal rate and student satisfaction, supporting the assumption that the error variances are equal across groups. However, the Levene test of equality of error variances is significant for grade. Finally, the linearity and multicollinearity among dependent variables were examined using Bartlett's test of sphericity and VIF. The results of Bartlett's test indicate a significant level of correlation $(\mathrm{p} \leq .01)$ between the three dependent measures and VIF values less than 10. Though not every assumption was completely met for this study's dataset, the areas in which data diverge from assumptions do not have a mate,rial effect on the outcomes. For example, with respect to the nonmultivariate normality, Stevens (1992) indicates that "deviation from multivariate normality has a small effect on Type I error" (p. 247). And while the equality of error variances for grade is not supported, only an approximation of equivalence is necessary for the assumptions to hold. Therefore, a multivariate test of significance was conducted to examine Wilks' lambda for paradigm development, course level, and paradigm development*course level (see Table 3). Wilks' lambda ranges between 0 and 1 , with values close to 0 indicating the group means are different and values close to 1 indicating the group means are not different (equal to 1 indicates all means are the same). That is, a significant difference is obtained from Wilks' lambda by getting small calculated values. An approximate F-statistic derived from Wiks' lambda is used to test for the significance of the overall MANCOVAs. Approximate F-statistics and degree of freedom (df) are shown in Table 3. Paradigm development, course level, and their interaction are all highly significant at the $1 \%$ level. Not surprisingly, all covariates except Year (a proxy for the different versions of (WebCT) and class size are significant.

Table 3: Multivariate Test of Significance

\begin{tabular}{|l|c|c|c|c|}
\hline Effect & Wilks' Lamda & F STATISTIC & $\begin{array}{l}\text { Degree of Free- } \\
\text { dom (Df) }\end{array}$ & $\begin{array}{l}\text { Significance Level } \\
(\mathrm{p})\end{array}$ \\
\hline Paradigm Dev. & .788 & 10.591 & 3.000 & .000 \\
\hline Course Level & .784 & 10.814 & 3.000 & .000 \\
\hline $\begin{array}{l}\text { Paradigm Dev. } \\
\text { * Course Level }\end{array}$ & .835 & 7.754 & 3.000 & .000 \\
\hline Covariates & .816 & 8.872 & 3.000 & .000 \\
\hline Age & .967 & 1.324 & 3.000 & .270 \\
\hline Class size & .778 & 11.253 & 3.000 & .000 \\
\hline Total SAT & .575 & 29.065 & 3.000 & .000 \\
\hline University GPA & .124 & 276.771 & 3.000 & .000 \\
\hline $\begin{array}{l}\text { Perceived course } \\
\text { quality }\end{array}$ & .987 & .530 & 3.000 & .662 \\
\hline Year & & & & \\
\hline
\end{tabular}




\section{Univariate Analyses Results}

As a consequence of the significant multivariate test (See the significance level in Table 3), univariate tests analyzing the variance for each variable are also reported (see Table 4). Grades are significantly higher for students taking courses in disciplines with high paradigm development (mean $=3.44$, std dev $=0.287)$ than in low paradigm development disciplines $($ mean $=2.94$, std $\mathrm{dev}=0.466)(\mathrm{F}$ statistic $=9.417, \mathrm{p} \leq .003)$. The difference is significant. Student satisfaction is not significantly lower in high paradigm courses (mean $=2.04$, std dev $=0.534)$ than in low paradigm courses $($ mean $=2.03$ std dev $=0.448)(\mathrm{F}$ statistic $=1.421, \mathrm{p} \leq .236)$. Withdrawal rate is significantly lower in high paradigm courses (mean $=0.05$, std dev $=0.049)$ than in low paradigm courses (mean $=0.13$, std dev $=0.105)(\mathrm{F}$ statistic $=17.829, \mathrm{p} \leq .01)$. In terms of course level, only the withdrawal rate is significantly different $(\mathrm{F}$ statistic $=31.230, \mathrm{p} \leq 0.01)$. The interaction between paradigm and course level is significant for both withdrawal rate and satisfaction ( $\mathrm{F}$ statistic $=20.748, \mathrm{p} \leq 0.01$ and $\mathrm{F}$ statistic $=4.079, \mathrm{p} \leq 0.046$, respectively). The only covariate that is significant for Grade is GPA (F statistic $=14.129, \mathrm{p} \leq 0.01$ ). Only Class Size and Year are insignificant as covariates when considering withdrawal rate and satisfaction.

Table 4: Selected Results of Between-Subjects Effects

\begin{tabular}{|c|c|c|c|c|c|c|}
\hline Source & $\begin{array}{l}\text { Dependent } \\
\text { Variable }\end{array}$ & $\begin{array}{l}\text { Type III } \\
\text { Sum of } \\
\text { Squares }\end{array}$ & $\begin{array}{l}\text { Degree of } \\
\text { Freedom } \\
\text { (df) }\end{array}$ & $\begin{array}{l}\text { Mean } \\
\text { Square }\end{array}$ & $\begin{array}{l}\text { F } \\
\text { Statistic }\end{array}$ & $\begin{array}{l}\text { Significance } \\
\text { level (p) }\end{array}$ \\
\hline \multirow[t]{3}{*}{ Corrected Model } & Grade & $12.786(a)$ & 9 & 1.421 & 10.600 & .000 \\
\hline & Withdrawal & $.782(b)$ & 9 & .087 & 26.116 & .000 \\
\hline & Satisfaction & $27.755(\mathrm{c})$ & 9 & 3.084 & 170.217 & .000 \\
\hline \multirow[t]{3}{*}{ Intercept } & Grade & .002 & 1 & .002 & .013 & .908 \\
\hline & Withdrawal & .003 & 1 & .003 & .806 & .371 \\
\hline & Satisfaction & .016 & 1 & .016 & .860 & .356 \\
\hline \multirow[t]{3}{*}{ SAT } & Grade & .000 & 1 & .000 & .001 & .974 \\
\hline & Withdrawal & .085 & 1 & .085 & 25.708 & .000 \\
\hline & Satisfaction & .192 & 1 & .192 & 10.594 & .001 \\
\hline \multirow[t]{3}{*}{ GPA } & Grade & 1.894 & 1 & 1.894 & 14.129 & .000 \\
\hline & Withdrawal & .202 & 1 & .202 & 60.847 & .000 \\
\hline & Satisfaction & .109 & 1 & .109 & 6.022 & .016 \\
\hline \multirow[t]{3}{*}{ Age } & Grade & .070 & 1 & .070 & .523 & .471 \\
\hline & Withdrawal & .046 & 1 & .046 & 13.788 & .000 \\
\hline & Satisfaction & .238 & 1 & .238 & 13.162 & .000 \\
\hline \multirow[t]{3}{*}{ Class Size } & Grade & .131 & 1 & .131 & .977 & .325 \\
\hline & Withdrawal & .002 & 1 & .002 & .615 & .435 \\
\hline & Satisfaction & .042 & 1 & .042 & 2.342 & .129 \\
\hline
\end{tabular}




\begin{tabular}{|c|c|c|c|c|c|c|}
\hline Source & $\begin{array}{l}\text { Dependent } \\
\text { Variable }\end{array}$ & $\begin{array}{l}\text { Type III } \\
\text { Sum of } \\
\text { Squares }\end{array}$ & $\begin{array}{l}\text { Degree of } \\
\text { Freedom } \\
\text { (df) }\end{array}$ & $\begin{array}{l}\text { Mean } \\
\text { Square }\end{array}$ & $\begin{array}{l}\text { F } \\
\text { Statistic }\end{array}$ & $\begin{array}{l}\text { Significance } \\
\text { level (p) }\end{array}$ \\
\hline \multirow[t]{3}{*}{ Year } & Grade & .001 & 1 & .001 & .008 & .927 \\
\hline & Withdrawal & .003 & 1 & .003 & .858 & .356 \\
\hline & Satisfaction & .015 & 1 & .015 & .817 & .368 \\
\hline \multirow{3}{*}{$\begin{array}{l}\text { Perceived } \\
\text { Teacher Quality }\end{array}$} & Grade & .480 & 1 & .480 & 3.582 & .061 \\
\hline & Withdrawal & .021 & 1 & .021 & 6.221 & .014 \\
\hline & Satisfaction & 14.290 & 1 & 14.290 & 788.779 & .000 \\
\hline \multirow{3}{*}{$\begin{array}{l}\text { Paradigm Devel- } \\
\text { opment }\end{array}$} & Grade & 1.262 & 1 & 1.262 & 9.417 & .003 \\
\hline & Withdrawal & .059 & 1 & .059 & 17.829 & .000 \\
\hline & Satisfaction & .026 & 1 & .026 & 1.421 & .236 \\
\hline \multirow[t]{3}{*}{ Course Level } & Grade & .139 & 1 & .139 & 1.038 & .310 \\
\hline & Withdrawal & .104 & 1 & .104 & 31.230 & .000 \\
\hline & Satisfaction & .064 & 1 & .064 & 3.513 & .063 \\
\hline \multirow{3}{*}{$\begin{array}{l}\text { Paradigm * } \\
\text { Course Level }\end{array}$} & Grade & .269 & 1 & .269 & 2.009 & .159 \\
\hline & Withdrawal & .069 & 1 & .069 & 20.748 & .000 \\
\hline & Satisfaction & .074 & 1 & .074 & 4.079 & .046 \\
\hline \multirow[t]{3}{*}{ Error } & Grade & 16.082 & 120 & .134 & & \\
\hline & Withdrawal & .399 & 120 & .003 & & \\
\hline & Satisfaction & 2.174 & 120 & .018 & & \\
\hline \multirow[t]{3}{*}{ Total } & Grade & 1306.488 & 130 & & & \\
\hline & Withdrawal & 2.535 & 130 & & & \\
\hline & Satisfaction & 567.320 & 130 & & & \\
\hline \multirow[t]{3}{*}{ Corrected Total } & Grade & 28.868 & 129 & & & \\
\hline & Withdrawal & 1.181 & 129 & & & \\
\hline & Satisfaction & 29.929 & 129 & & & \\
\hline
\end{tabular}

\section{Hierarchical Moderated Regression Analysis Results}

The role of course level as a moderating variable was examined using three separate regression models (Sharma, Durnad, \& Gur-arie, 1981) to isolate the direct effect of each dependent variable from the interaction effect.: 
(Eqn 1) Outcome (i.e., Satisfaction, Grades, Withdrawal) $=a+b_{1}$ paradigm

(Eqn 2) Outcome (i.e., Satisfaction, Grades, Withdrawal) $=a+b_{1}$ paradigm $+b_{2}$ course level

(Eqn 3) Outcome (i.e., Satisfaction, Grades, Withdrawal) $=a+b_{1}$ paradigm $+b_{2}$ course level $+b_{3}$ paradigm* course level

Hierarchical moderated regression analyses performed on all three outcomes to determine the nature of the moderating effect yields a significant $R$ square $\left(R^{2}\right)$ and $R$ square change $\left(\Delta R^{2}\right)$ for withdrawal rate and student satisfaction only. Table 5 reports the results of the hierarchical regression analysis for moderated regression analysis for withdrawal rate and student satisfaction, the dependent variables demonstrating a moderator effect. According to Sharma et al. (1981), a moderator variable is one in which $b_{2}$ from equation $2=0$, and $b_{3}$ from equation 3 is not equal to 0 must be satisfied. However, Carte and Russell (2003) argued against simply looking at the beta coefficients and suggested, instead, the importance of testing the significance of the R square change $\left(\Delta R^{2}\right)$ from the various equations. We report the Sharma et al. (1981) beta results, the $R$ square change $\left(\Delta \mathrm{R}^{2}\right)$ and the F-Statistics in Table 5.

Table 5: Results of Hierarchical Moderated Regressions

\begin{tabular}{|c|c|c|c|c|c|c|c|}
\hline & $\begin{array}{l}\text { Betas } \\
(\text { Eqn 1) }\end{array}$ & $\begin{array}{l}\text { Betas } \\
\text { (Eqn2) }\end{array}$ & $\begin{array}{l}\text { Betas (Eqn } \\
\text { 3) }\end{array}$ & $\begin{array}{l}\mathrm{R} \\
\text { square } \\
\left(\mathrm{R}^{2}\right)\end{array}$ & $\begin{array}{l}\mathrm{R} \\
\text { square } \\
\text { change } \\
\left(\Delta \mathrm{R}^{2}\right)\end{array}$ & $\begin{array}{l}\text { Degree } \\
\text { of } \\
\text { Free- } \\
\text { dom } \\
\text { (df) }\end{array}$ & $\begin{array}{l}\text { F statis- } \\
\text { tics }\end{array}$ \\
\hline \multicolumn{8}{|c|}{ WITHDRAWAL RATE } \\
\hline $\begin{array}{l}\text { Paradigm De- } \\
\text { velopment }\end{array}$ & $\begin{array}{l}\mathrm{b} 1= \\
.023\end{array}$ & $\begin{array}{l}\mathrm{b} 1= \\
039 * * *\end{array}$ & $\begin{array}{l}\mathrm{b} 1= \\
.131 * * *\end{array}$ & .484 & & & \\
\hline Course Level & & $\begin{array}{l}\mathrm{b} 2= \\
-.067 * * *\end{array}$ & $\begin{array}{l}\mathrm{b} 2=\quad- \\
.009\end{array}$ & .553 & 0.069 & & \\
\hline $\begin{array}{l}\text { Paradigm De- } \\
\text { velopment x } \\
\text { Course Level }\end{array}$ & & & $\begin{array}{l}\mathrm{b} 3= \\
-.139 * * *\end{array}$ & .637 & 0.084 & $(1,120)$ & $29.62 * * *$ \\
\hline \multicolumn{8}{|c|}{ STUDENT SATISFACTION } \\
\hline $\begin{array}{l}\text { Paradigm De- } \\
\text { velopment }\end{array}$ & $\begin{array}{l}\mathrm{b} 1=\quad- \\
.015\end{array}$ & $\begin{array}{l}\mathrm{b} 1= \\
-.036\end{array}$ & $\mathrm{~b} 1=.031$ & .908 & & & \\
\hline Course Level & & $\begin{array}{l}\mathrm{B} 2= \\
-.058\end{array}$ & $\mathrm{~b} 2=.010$ & .910 & .002 & & \\
\hline $\begin{array}{l}\text { Paradigm De- } \\
\text { velopment x } \\
\text { Course Level }\end{array}$ & & & $\begin{array}{l}\mathrm{b} 3= \\
.144 * *\end{array}$ & .922 & .012 & $(1,120)$ & $19.69 * * *$ \\
\hline
\end{tabular}

In Table 5, we see that both $b_{2}(-.067)$ from equation 2 and $b_{3}(-.139)$ from equation 3 are significant at the $1 \%$ level for withdrawal rate. This result indicates that course level is both a quasi- 
moderator variable (Sharma et al. 1981) as it interacts with the predictor variable paradigm, and a predictor variable.

The $\mathrm{R}$ square change $\left(\Delta \mathrm{R}^{2}\right)(.084)$ and $\mathrm{F}$ statistic $(29.62, \mathrm{p} \leq .01)$ also support the hypothesis that course level moderates the relationship between paradigm development and withdrawal rate. This moderating effect can be seen in Figure 3 where withdrawal rate is highest for advanced low paradigm courses (mean $=.243$ ) and for introductory low paradigm courses (mean $=.118)$. Withdrawal rate is lowest for advanced high paradigm courses $($ mean $=.038)$ and introductory high paradigm courses $($ mean $=.082)$. These results support Hypotheses 2 and 4.

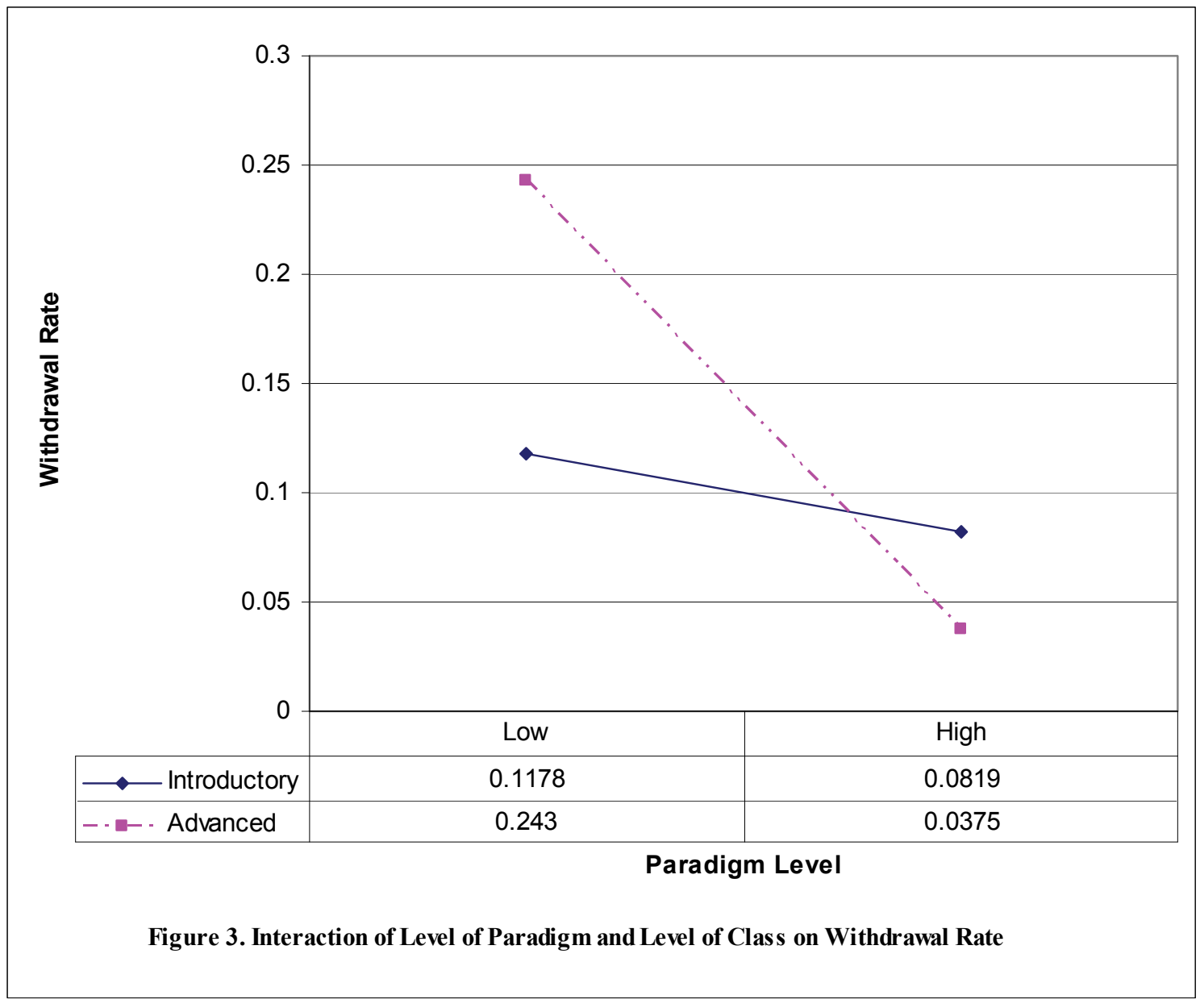

An examination of student satisfaction, from Table 5, shows that $b_{2}(-.058)$ from equation 2 is not significant at the usual significance level (significance level $p=.266)$ while $b_{3}(-.144)$ from equation 3 is significant at the $5 \%$ level (significance level $\mathrm{p}=.046)$. The change (.012) and F statistic $(19.69, \mathrm{p} \leq .01)$ demonstrate that the interaction between course level and paradigm development for student satisfaction moderates the relationship and is in the hypothesized direction since the highest level of satisfaction is coded with a ' 1 ' and the lowest level is coded with a ' 5 '. This moderating effect can be seen in Figure 4 where student satisfaction scores are lowest (i.e., higher satisfaction) for advanced high paradigm courses (mean =1.82) and for introductory low paradigm courses (mean $=1.96)$. The student satisfaction score is highest (i.e., indicating lower satisfaction) for advanced low paradigm courses $($ mean $=2.48)$ and introductory high paradigm courses (mean $=2.44$ ). The result relationships are in the direction predicted by Hypotheses 1 and 3. 


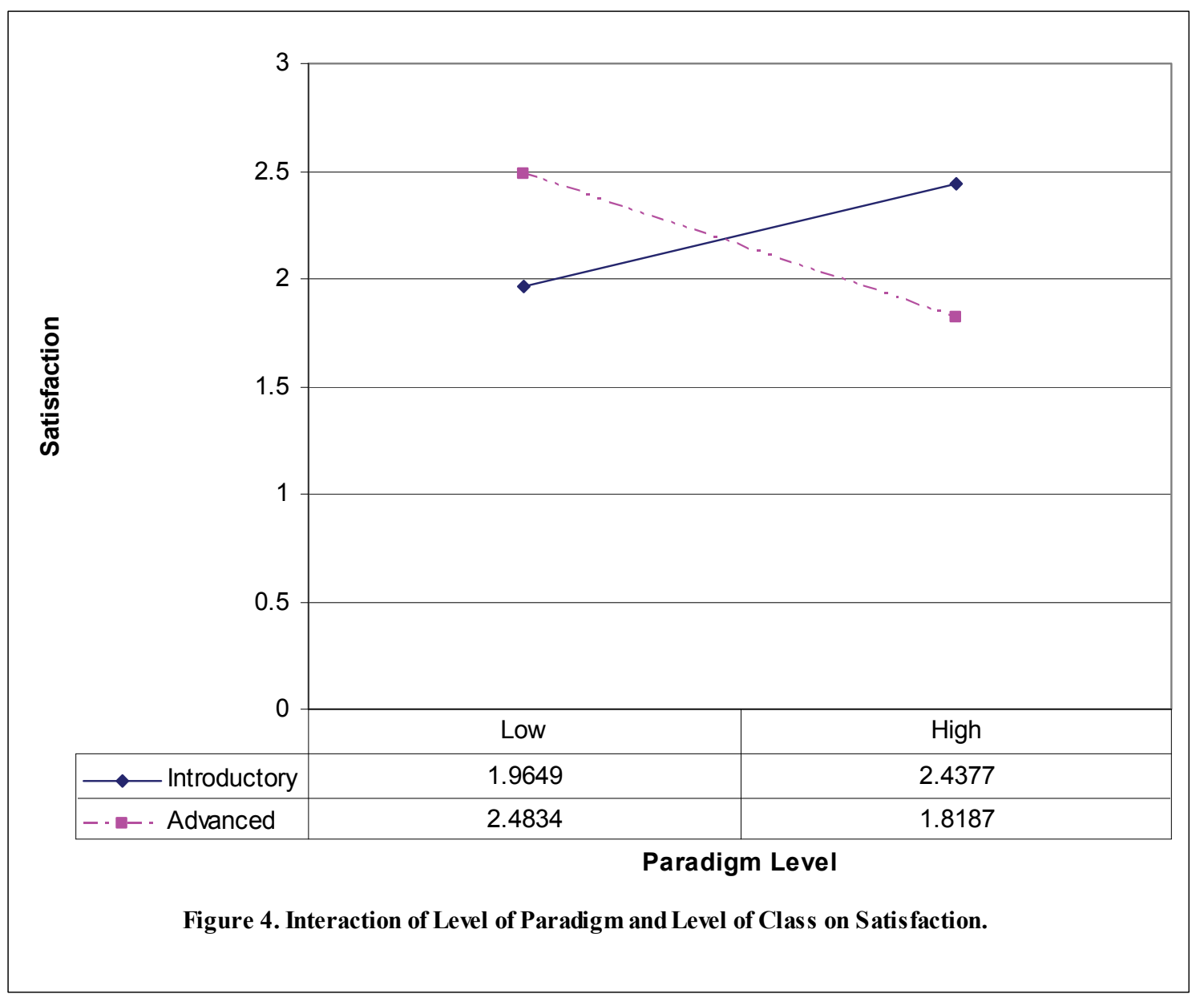

\section{Discussion}

Information Technology can be used more effectively for some courses, but not others. Using a large sample of classes taught over a six-year period, we find that student performance in technology-mediated learning environments is significantly greater for courses in disciplines with high paradigm development than for courses in disciplines with low paradigm development. Also, in the high paradigm courses, withdrawal rate is significantly lower, and an even stronger significant relationship emerges when we include the hypothesized moderating effect of course level on the relationship. Further, the hypothesized significant relationship emerges when we include the moderating effect of course level on the relationship with student satisfaction.

As in the studies by Vaverek \& Saunders (1993-1994) and Benbunan-Fich \& Hiltz (2002), students are more satisfied (but not significantly so) in the less technical, low paradigm courses. The use of course level as a moderator in this relationship explains the seemingly contrary findings of Vaverek \& Saunders (1993-1994) about the desirability of using IT in teaching courses in lowparadigm disciplines. In particular, students are clearly more satisfied in introductory, lowparadigm courses offered in TML environments than in advanced courses in these same disciplines. The reverse is true for high-paradigm courses: Students are more satisfied in the advanced courses. When assessing student satisfaction, investigating only level of paradigm development masks some important differences.

Probably the most notable findings of this study relate to the impact of paradigm development on the withdrawal rate in technology-mediated learning environments. The use of course level as a 
moderator in this relationship tempers Webster and Hackley's (1997) findings concerning the high withdrawal rate in technology-mediated learning environments. They reported, “... in one course students told us that the technology had scared off many students: one location dropped to 4 students from 14." Our findings suggest that students in courses in disciplines with high levels of paradigm development may not be scared off as easily as those in low-paradigm disciplines at any level, but especially in the more advanced courses.

These findings have important practical implications for Management Information Systems (MIS) education. MIS clearly does not have a single paradigm that characterizes such high-paradigm disciplines as physics and chemistry (e.g., Hassan, 2006). Further, there is considerable debate about its core. Defining the core of a discipline is a task that is easy to do in disciplines with a high-level of paradigm development. We operationalized level of paradigm development with an approach that has been commonly used in past research, course sequencing in departments (e.g., Pfeffer \& Moore, 1980; Salancik et al., 1980). The short chain of only three prerequisites at the university in which the study was conducted is consistent with viewing MIS as a low paradigm discipline. Our findings indicate that for such programs, the TML environment approach may not be as effective in terms of supporting satisfaction and learning and may in fact lead to higher withdrawal rates for more advanced, highly technical courses. On the other hand, the outcomes should be successful for technology-mediated introductory MIS courses. In our study, only one MIS course has been entirely web-based, the introductory undergraduate business core course. The mean (standard deviation) for student grades, withdrawal rate and student satisfaction are $2.96(0.29), 0.085(0.055)$, and $2.80(0.55)$, respectively, suggesting the appropriateness of using IT for the introductory MIS course. The MIS classes were not significantly different from the other courses in low paradigm disciplines in terms of grades and withdrawal rates.

We are surprised that relatively few web-based courses in high paradigm disciplines were taught at the University over the six- year period of our study. Looking at the entire database of all courses in all disciplines (not just high and low paradigm development disciplines), only an approximate four percent of the participating disciplines (i.e., 4 out of 95) and the total number of the web-based sections (i.e., 79 out of 2021) are in high paradigm development disciplines.

To try to better understand why the high-paradigm disciplines were not better represented in our sample, we placed follow-up calls with the department chairs or the faculty whom the chairs recommended that we contact in their department. The Departments of Mathematics, Computer Science, Physics, and Biology were contacted to further explore why their departments (in highparadigm disciplines) had not developed more courses that were entirely web-based. While they had only offered one undergraduate course in the past, the Computer Science department now has been charged by its Dean to place more classes online. The Physics department felt that it was important for their students to work in the labs with equipment and so the department was hesitant about using courses that were entirely web-based. Further, the Physics departmental spokesperson said that there were not enough graphics available to faculty teaching the TML courses to easily convey much of the material in physics courses. Finally the Biology Department had offered one course that was totally web-based, but has ceased offering it because it wants it students to work in the labs.

The response of the Mathematics department chair was particularly revealing. He said that it was important to allow face-to-face contact with the students when they had questions. His focus was entirely on the introductory courses, where our model suggests that TML environments are not as appropriate. In math courses there is the added difficulty of having to use a special symbol set to write equations. Software is available to make this easier for the faculty and students, but the chair thought that the costs were still too high to incorporate it into courses that are entirely webbased. Media Synchronicity Theory suggests that media with more natural system sets, such as face-to-face communications, can support interactive discussions better than less natural symbol 
sets such as mathematical symbols (Dennis, Fuller, \& Valacich, in press). Hence, the math teachers could be expected to find it more difficult to communicate with their students online.

Our discussions with the department chairs and faculty in high-paradigm disciplines demonstrate that professors may be averse to teaching such courses because of concerns about the appropriateness of technology-mediated delivery. If so, our findings suggest that some of their concerns may be ill-founded: Students in disciplines with high levels of paradigm development perform better in their web-based courses than students in courses with low levels of paradigm development. However, they would need to target TML environments for advanced courses in these disciplines, especially those that do not require lab equipment.

Perhaps, the University technology support staff needs to work more closely with professors in such fields as Mathematics and Physics to persuade them to use the TML environment. In working with faculty in disciplines with high levels of paradigm development, it may be especially important to identify the advanced courses for which the technology would be suitable and to stress the need for faculty to provide timely feedback to students in introductory classes who might withdraw or do poorly in the course because they do not understand basic concepts. Further, the technology support staff members need to make software available that makes it easier for faculty to use graphics and mathematical symbols. If such software is already available at the university, the faculty need to be alerted about its potential use in courses.

Heavy emphasis on online discussions among students during in the TML environment courses that we studied could provide an alternative explanation for the lower proportion of classes in disciplines with high paradigm development. This University adopts a constructivist model in TML environment training so that learning takes place as students construct knowledge - active discovery supported by the instructor. Since the terms and concepts of low level paradigm fields are less developed/agreed upon, there is a greater necessity for student interaction to support their construction of knowledge, often through discussions with their peers. In contrast, under the objectivist model, learning takes place as the student absorbs the knowledge of the instructor. No interactivity is necessary between the students and their classmates. Therefore it might be argued that the greater the paradigm development, the less need for interaction (other than that of instructor to student). Hence, faculty in disciplines with high paradigm development may view webbased courses as less appropriate since they do not value discussion among students. In these situations there may not be a good fit with teaching styles, or responsiveness and enthusiasm of the instructor for the technology platform (Hornik, Johnson \& Wu, 2007; Sarker \& Nicholson, 2005). University technical staff may need to alter their training programs to focus on ways of interacting with equipment instead of other classmates.

Of course, faculty teaching in either high or low paradigms may resist using the technology because they recognize that it may be more difficult to prepare material for the course, it requires more effort to interact with students during the course, or it may lead to undesirable use of course materials (Sarker \& Nicholson, 2005). Universities that wish to encourage more teaching in TML environments will need to incentivize faculty by recognizing the considerable efforts to develop and teach these course with merit increase and other forms of recognition. Further, universities must take an active role in protecting faculty's intellectual property.

\section{Limitations}

This study is not without limitations. While virtually all of the MANOVA assumptions were met, grade did not meet the assumption for homoscedasity. Thus, the results of MANOVA related to grade must be viewed critically. However as mentioned above, violations of the assumptions

have been found to not have a material effect on the results (Stevens, 1992). Another limitation in this research involves control variables. Studies of student withdrawal in TML environments 
suggests that the number of previous technology-mediated courses taken by students reliably discriminates between students who drop out compared to those who remain in either web-based or videoconferencing courses (Osborn, 2001; Wang \& Newlin, 2002). Future studies should control for the number of previous technology-mediated courses and the reasons for student withdrawals. Also, future research should incorporate ratio scales and should explore the reasons for lower adoption rates in courses with high paradigm development. Other types of TML environments and characteristics should also be studied, such as Blackboard or Persyst (Ginsberg, Shiau, \& Sampieri, 2000). This study clearly demonstrates that educational technology is more important for certain courses when considering paradigm development. The findings from this study suggest that future research should explore what aspects of the technology cause these differences across paradigm development and course level to occur.

\section{Conclusion and Recommendations}

This paper investigates the effect of paradigm development and course level on the outcomes of web-based technology-mediated learning (TML) environments in order to ascertain if these external factors can help explain student outcomes. Using an institutional database of student outcomes, we examined data from over 13,000 students in 167 undergraduate courses from the years 1997 - 2003. Using this data we explored which types of courses are best suited for delivery using web-based technologies. We find that some courses are clearly more suitable for TML environments than others. Tests of our hypotheses suggest just which types of courses are more suitable. In particular, our results suggest that student grades are significantly higher and withdrawal rates lower for courses with high paradigm development (e.g., Biology, Computer Science) than for courses with low paradigm development (e.g., Sociology, English). Even stronger relationships emerge when including the hypothesized moderating effect of course level (introductory or advanced). In introductory TML courses in disciplines with lower paradigm development, grades and student satisfaction are higher (Hypothesis 1) and withdrawal rates are lower (Hypothesis 2) than in introductory TML courses in disciplines with high paradigm development. In contrast, in advanced TML courses in disciplines with low paradigm development, grades and student satisfaction are lower (Hypothesis 3) and withdrawal rates are higher (Hypothesis 4) than in advanced TML courses with high paradigm development in TML environments.

As more TML programs are developed, these findings highlight the importance of creating programs in high paradigm development disciplines. We found amazingly few course offerings in these disciplines during the six-year period of our study. Given the findings of improved student outcomes, more advanced TML courses in these disciplines should be developed, especially those that do not have lab requirements.

In creating and enhancing TML programs we have the following suggestions for University administrators, faculty and students. These are outlined below:

\section{University administrators}

- University administrators should recognize that TML environments require considerable technical support. They should hire adequate staff to support faculty in their efforts to develop new courses. For example, technical support staff could be assigned to work with faculty who have proposed new web-based courses.

- University administrators should provide incentives for faculty to develop web-based courses. Faculty could be given release time to develop courses and could be recognized for their considerable efforts at developing and offering courses when faculty are evaluated and merit is determined. 
- University administrators should recognize and protect the intellectual property of faculty who develop TML courses.

- University administrators should make funding available for needed technology, such as software to make it easier to use graphics and mathematical symbols.

\section{Faculty}

- Faculty should recognize that TML environments are not appropriate for all courses. Thus, faculty in disciplines with low levels of paradigm development should target introductory courses, and faculty in disciplines with high levels of paradigm development should target the more advanced courses. Since many science classes need students to work in labs, these classes may require a mixed format with both an online and a lab component.

- Faculty must be available to provide prompt feedback to students. This is especially critical in courses where students need to master elementary concepts before they can move on to more advanced concepts.

\section{Students}

- Students may wish to seek out introductory, entirely web-based courses in low-paradigm disciplines and advanced courses that are entirely web-based in high-paradigm disciplines, because these formats may be particularly appropriate for their learning.

- Students need to make sure they ask for help from the faculty members as soon as they realize that they do not understand key concepts.

To maximize the return on new TML initiatives, a focused program for creating new online courses for advanced high paradigm development courses (e.g., Computer Science) and introductory courses in low-paradigm disciplines should lead to less withdrawal, higher satisfaction, and increased academic performance. It will require, however, the concerted efforts of administrators, faculty and students.

\section{References}

Agarwal, R., \& Lucas, H. (2005). The information systems identity crisis: Focusing on high-visibility and high-impact research. MIS Quarterly, 29(3), 381-398.

Alavi, M., \& Leidner, D. E. (2001). Research commentary: Technology mediated learning - A call for greater depth and breadth of research. Information Systems Research, 12(1), 1-10.

Anderson, L., \& Krathwohl, D. (2001). A taxonomy for learning, teaching, and assessing: A revision of bloom's taxonomy of educational objectives. New York: Longman.

Arbaugh, J. B. (2001). How instructor immediacy behaviors affect student satisfaction and learning in webbased courses. Business Communication Quarterly, 64(4), 42-53.

Arbaugh, J. B., \& Duray, R. (2002). Technological and structural characteristics, student learning and satisfaction with web-based courses: An exploratory study of two MBA programs. Management Learning, $33,331-347$.

Benbasat, I. \& R. W. Zmud (2003). The identity crisis within the IS discipline: Defining and communicating the discipline's core properties. MIS Quarterly, 27(2), 183-194.

Benbunan-Fich, R., \& Hiltz, R. (2002). Correlates of effectiveness of learning networks: The effects of course level, course type, and gender on outcomes. Paper presented at the 35th Annual Hawaii International Conference on System Sciences. 
Beyer, J. M. (1978). Editorial policies among leading journals in four scientific fields. The Sociological Quarterly, 19, 68-88.

Biner, P. M. (1993). The development of an instrument to measure student attitudes toward televised courses. The American Journal of Distance Education, 7(1), 63-73.

Bloom, B., Engelhart, M., Furst, E., Hill, W., \& Krathwohl, D. (1956). Taxonomy of educational objectives: The classification of educational goals, by a committee of college and university examiners. New York: McKay.

Carte, T., \& Russell, C. (2003). In pursuit of moderation: Nine common errors and their solutions. MIS Quarterly, 27(3), 479-500.

Cheng, J. L. C. (1984). Paradigm development and communication in scientific settings: A contingency analysis. Academy of Management Journal, 27(4), 870-877.

Christophel, D. (1990). The relationships among teacher immediacy behaviors, student motivation and learning. Communication Education, 39, 323-340.

Chyung, S.-Y., \& Stepich, D. (2003). Applying the "congruence" principle of Bloom's taxonomy to designing online instruction. The Quarterly Review of Distance Education, 4(3), 317-330.

Cohen, J. (1960) A Coefficient of Agreement for Nominal Scales. Educational and Psychological Measurement, 20(1), 37-46.

Daft, R., \& Lengel, R. (1986). Organizational information requirements, media richness and structural design. Management Science, 32, 554-571.

Dennis, A. R., Fuller, R. M., \& Valacich, J. S. (in press). Media, tasks and communication processes: A theory of media synchronicity. MIS Quarterly.

Dumort, A. (2000). New media and distance education: An EU-US perspective. Information, Communication \& Society, 3(4), 546-556.

Dutton, J., Dutton, M., \& Perry, J. (2001). Do online students perform as well as lecture students? Journal of Engineering Education, 90(1), 131-136.

Dzubian, C. D., Wang, M. C., \& Cook, I. J. (2003). Dr. Fox rocks: Student perceptions of excellent and poor teaching. Unpublished manuscript, University of Central Florida, Orlando, Florida.

Galt Gobal Review. (2001). Education news: Virtual classrooms booming. Retrieved August 5, 2002, from http://www.galtglobalreview.com/education/virtual_classrooms.html

Ginsberg, A., Shiau, D., \& Sampieri, B. (2000). Using a virtual room platform to build a multimedia distance learning environment for the internet. Informing Science Journal, 3(1), 15-22. Retrieved from http://inform.nu/Articles/Vol3/v3n1p15-22.pdf

Gunawardena, C. N. (1995). Social presence theory and implications for interaction and collaborative learning in computer conferences. International Journal of Educational Telecommunications, 1, 147166.

Hassan, N. (2006). Is information systems a discipline: A Foucauldian and Toulminian analysis. Paper presented at the Twenty Seventh International Conference on Information Systems (ICIS), Milwaukee, WI.

Higgs, M. D., \& Wood, R. (1999, August). Individual adaptation strategies on work role transitions. Paper presented at the Academy of Management National Meeting, Chicago.

Hiltz, S. R., \& Wellman, B. (1997). Asynchronous learning networks as a virtual classroom. Communications of the $A C M, 40(9), 44-52$.

Hornik, S. R., Johnson, R. D., \& Wu, Y. (2007). When technology does not support learning: The negative consequences of dissonance of individual epistemic beliefs in technology mediated learning. Journal of Organizational and End User Computing, 19(2), 23-46. 
Impact of Paradigm Development and Course Level

Kuhn, T. S. (1970). The structure of scientific revolutions (2nd ed.). Chicago: University of Chicago Press.

Landis, J. R., \& Koch, G. G. (1977). The measurement of observer agreement for categorical data. Biometrics 33, 159-174.

Lodahl, J. B., \& Gordon, G. (1972). The structure of scientific fields. American Sociological Review, 37, 57-72.

Lu, J., Yu, C.-S., \& Liu, C. (2003). Learning style, learning patterns, and learning performance in a WebCT-based MIS course. Information \& Management, 40(6), 497-507.

McDonald, J. (2002). Is "as good as face-to-face" as good as it gets? Journal of Asynchronous Learning Networks, 6(2), 10-23.

Nunally, J. C., \& Bernstein, I. H. (1994). Psychometric Theory (3rd ed.). New York: McGraw-Hill.

Osborn, V. (2001). Identifying at-risk students in video conferencing and web-based distance education. American Journal of Distance Education, 15, 41-54.

Pfeffer, J., \& Moore, W. L. (1980). Power in university budgeting: A replication and extension. Administrative Science Quarterly, 25, 387-406.

Phipps, R., \& Merisotis, J. (1999). What's the difference? A review of contemporary research on the effectiveness of distance learning in higher education. Washington, DC: Institute for Higher Education Policy.

Picciano, A. G. (1998). Developing an asynchronous course model at a large, urban university. Journal of Asynchronous Learning Networks, 2(1), 1-14.

Piccoli, G., Ahmad, R. \& Ives, B. (2001). Web-based virtual learning environments: A research framework and a preliminary assessment of effectiveness in basic IT skills training. MIS Quarterly, 25(4), 401426.

Richardson, J. C., \& Swan, K. (2003). Examining social presence in online courses in relation to students' perceived learning and satisfaction. Journal of Asynchronous Learning Networks, 7(1), 68-88.

Robey, D. (2003) Identity, legitimacy and the dominant research paradigm: An alternative prescription for the IS discipline. Journal of the Association for Information Systems, 4(7), 352-359.

Russell, T. L. (1999). The no significant difference phenomenon: A comparative research annotated bibliography on technology for distance education. Raleigh, NC: Office of Instructional Telecommunications.

Salancik, G., Staw, B. M., \& Pondy, L., R. (1980). Administrative turnover as a response to unmanaged organizational interdependence. Academy of Management Journal, 23, 422-437.

Sarker, S., \& Nicholson, J. (2005). Exploring the myths about online education in information systems. Informing Science Journal, 8, 55-73. Retrieved from http://inform.nu/Articles/Vol8/v8p055073Sarker.pdf

Sharma, S., Durnad, R. M., \& Gur-arie, O. (1981). Identification and analysis of moderator variables. Journal of Marketing Research, 18, 291-300.

Stevens, J. (1992). Applied multivariate statistics for the social sciences (2nd. ed.). Hillsdale, NJ.: Lawrence Erlbaum.

Sutton, L. (2001). The principle of vicarious interaction in computer-mediated communications. International Journal of Educational Telecommunications, 7(3), 223-242.

Swan, K. (2003). Learning effectiveness: What the research tells us. In J. Bourne \& J. Moore (Eds.), Elements of quality online education (Vol. 4, pp. 12-45). Olin and Babson Colleges: Sloan Center for Online Education. 
Swan, K., Shea, P., Fredericksen, E., Pickett, A., Pelz, W., \& Maher, G. (2000). Building knowledge building communities: Consistency, contact and communication in the virtual classroom. Journal of Educational Computing Research, 23(4), 389-413.

VandeWalle, D., Cron, W. L., \& Slocum, J. W., Jr. (2001). The role of goal orientation following performance feedback. Journal of Applied Psychology, 86(4), 629-640.

Vaverek, K. A., \& Saunders, C. S. (1993-1994). Computerspeak: Message content and perceived appropriateness in an educational setting. Journal of Educational Technology Systems, 22(2), 123-140.

Wang, A. Y., \& Newlin, M. H. (2002). Predictors of web-student performance: The role of self-efficacy and reasons for taking an on-line class. Computers in Human Behavior, 18(2), 151-163.

Webster, J., \& Hackley, P. (1997). Teaching effectiveness in technology-mediated distance learning. Academy of Management Journal, 40(6), 1282-1309.

Wirt, J., \& Livingston, A. (2002). Condition of education 2002 in brief. Retrieved August 28th, 2003, from http://nces.ed.gov/pubsearch/pubsinfo.asp?pubid=2002011

\section{Biographies}

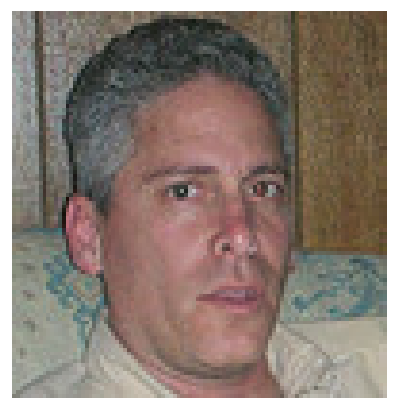

Steven Hornik is a faculty member of the Dixon School of Accounting at the University of Central Florida, College of Business Administration. His research interests include the social context of technology mediation in learning, training and other virtual environments, the effectiveness of technology mediated learning for training and higher education and the social implications of technology. He has been involved in the Research Initiative for Teaching Effectiveness, University of Central Florida, to examine the impact of distance learning outcomes and was selected as a 2005 UCF Fellow of the Academy for Teaching, Learning -and Leadership. Dr. Hornik has published in several journals including Journal of Global Information Management, Journal of Organizational End User Computing, IEEE Transactions on Professional Communication, and Journal of Information Systems.

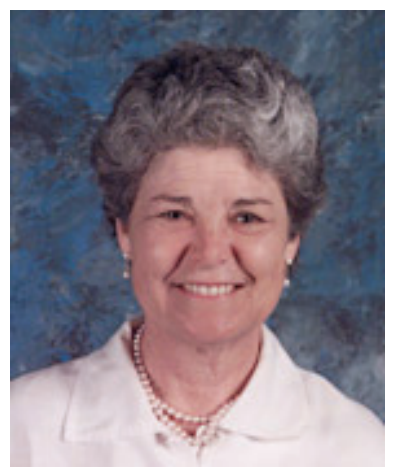

Carol Stoak Saunders is Professor of MIS at the University of Central Florida. She served as General Conference Chair of ICIS'99 and Telecommuting '96. She was the Chair of the Executive Committee of ICIS in 2000 and inducted as an AIS Fellow in 2003. She was Editorin-Chief of MIS Quarterly from 2005-2007. Her current research interests include the organizational impacts of information technology, virtual teams, time, and interorganizational linkages. Her research is published in MIS Quarterly, Information Systems Research, Journal of MIS, Journal of AIS, Communications of the ACM, Academy of Management Journal, Academy of Management Review, and Organization Science. She and Keri Pearlson coauthored Managing and Using Information Systems: A Strategic Approach, $3^{\text {rd }}$ edition. 

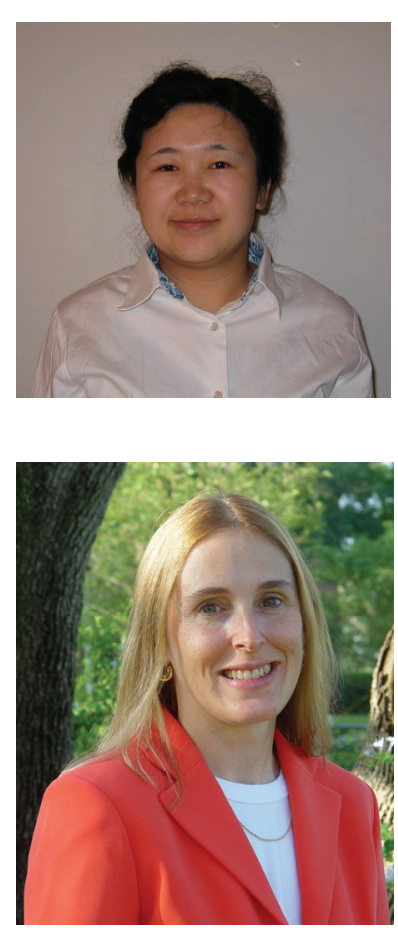

Yuzhu Li is a PhD candidate in MIS doctoral program at University of Central Florida. She has received Master of Technology Management in Washington State University, Washington, USA. Her research interests include project management, technology-mediated learning, and the use of IT in organizations. Her work has been published in journals such as Information and Management and the International Journal of Networking and Virtual Organization. articles on research in online and blended courses.

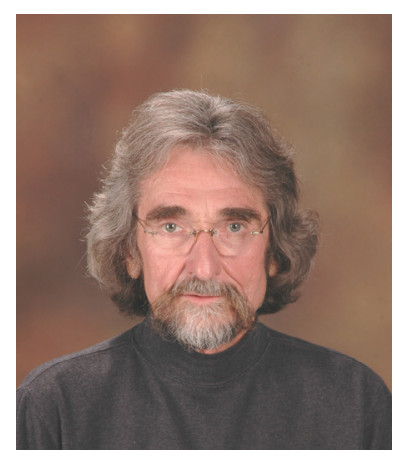

Charles Dziuban is Director of the Research Initiative for Teaching Effectiveness at the University of Central Florida (UCF) where has been a faculty member since 1970 teaching research design and statistics. He received his Ph.D. from the University of Wisconsin. Since 1996, he has directed the impact evaluation of UCF's distributed learning initiative examining student and faculty outcomes as well as gauging the impact of online courses on the university. Chuck has published in numerous journals including Multivariate Behavioral Research, The Psychological Bulletin, Educational and Psychological Measurement, the American Education Research Journal, the Phi Delta Kappan, the Internet in Higher Education, the Journal of Asynchronous Learning Networks, and the Sloan-C View. He has co-authored or edited numerous books and chapters on blended and online learning including Handbook of Blended Learning Environments, Educating the Net Generation, and Blended Learning: Research Perspectives. 